\title{
HIRING MERCENARIES IN THE CLASSICAL GREEK WORLD. CAUSES AND OUTCOMES?
}

\section{LA CONTRATACIÓN DE MERCENARIOS EN LA GRECIA CLÁSICA. ¿CAUSAS Y CONSECUENCIAS?}

\author{
MatTHew TRUnde \\ The University of Auckland
}

\begin{abstract}
This paper explores the reasons why employers hired mercenaries in the Classical Greek World of the fifth and fourth century BCE. It discusses the rise of mercenary activity against the backdrop of socio-economic and political phenomena that created the conditions for a large number of men to find service overseas especially in the Persian Empire. Mercenary service in an ancient Greek context is complicated by traditions that valued heroic service of aristocrats and rulers abroad in the past, for example as extolled in the poems of Homer, and that 'mercenary' is perhaps not an accurate label for men serving others abroad. Ultimately, the paper affirms the demand driven nature of such service and the wars of the fourth century in which Greeks served as products of great events extraneous to the mercenary service itself.
\end{abstract}

Keywords: Classical Greek, mercenary, Misthophoros, Xenos, Persian Empire.

\section{RESUMEN}

Este artículo explora las razones por las que los distintos empleadores contrataban los servicios de mercenarios en la Grecia Clásica durante los siglos $\mathrm{V}$ y IV a.C. Analiza el aumento de la actividad mercenaria teniendo como telón de fondo los fenómenos de índole política y socioeconómica que crearon las condiciones para que un gran número de hombres pudieran encontrar empleos como tal en el extranjero, especialmente en el Imperio Persa. El mercenariado en el contexto Antigua Grecia es una cuestión complejizada por la existencia de tradiciones que valoraban servir heroicamente a aristócratas y gobernantes extranjeros, como por ejemplo se ensalzaba en los poemas de Homero, algo para lo que el término "mercenario" no sería quizá una definición adecuada. En última instancia, el presente artículo afirma que el mercenariado estaba claramente impulsado y respondía a una demanda existente que se tradujo en la presencia de griegos en buena parte de las guerras del siglo IV a.C., siendo protagonistas de eventos que iban más allá del propio servicio mercenario.

Palabras clave: Grecia Clásica, mercenario, Misthophoros, Xenos, Imperio Persa. 


\section{RESUM}

\section{La contractació de mercenaris en la Grècia Clàssica. ¿Causes i conseqüències?}

Aquest article explora les raons per les quals els diferents ocupadors contractaven els serveis de mercenaris en la Grècia Clàssica durant els segles V i IV a. de C. Analitza l'augment de l'activitat mercenària tenint com a teló de fons els fenòmens d'índole política i socioeconòmica que van crear les condicions per a que un gran nombre d'homes poguessin trobar ocupacions com a tal a l'estranger, especialment en l'Imperi Persa. El mercenariat en el context Antiga Grècia és una qüestió complexa per l'existència de tradicions que valoraven servir heroicament a aristòcrates i governants estrangers, com per exemple s'enaltia en els poemes d'Homer, cosa per a la que el terme "mercenari" no seria potser una definició adequada. En última instància, el present article afirma que el mercenariat estava clarament impulsat i responia a una demanda existent que es va traduir en la presència de grecs en bona part de les guerres del segle IV a. de C., sent protagonistes d'esdeveniments que anaven més enllà del propi servei mercenari. Paraules clau: Grècia Clàssica, mercenari, Misthophoros, Xenos, Imperi Persa. 
This paper explores the reasons why employers hire mercenaries through a specific analysis of ancient Greek poleis and their Mediterranean context in the later Classical period. The ancient Greeks are particularly interesting because they idealized the connection between citizenship and military service. ${ }^{1}$ Even though many who resided within Greek communities and who were not full citizens fought for the armies of those Greek states in some capacity or other, the Greeks still reified the connection between bearing arms and citizenship. ${ }^{2}$ Most Greek citizens were potential if not actual soldiers for their own cities and many who served did so as higher status heavily armed infantry men (hoplitai - hoplites) the cost of whose equipped excluded the poor and so cemented their status. They also appear to have served for others in great numbers and very willingly outside of their communities in the latter fifth and fourth centuries BCE as opportunities for military service and remuneration presented themselves. ${ }^{3}$ The classical Greek world represents an important period for understanding mercenary activity because of the scale of service in the period and the intricate socio-political relationships it and mercenary relationships demonstrated.

By the later classical age (431-323 BCE) many Greek citizens served other poleis on the mainland and non-Greek rulers overseas especially the Persian Kings in increasingly great numbers. ${ }^{4}$ There was essentially an explosion in

1 On hoplites and citizenship see van WEES (2004); HANSON (1995); PRITCHARD (2010: 1-62); RIDLEY (1979: 508-548); and CROWLEY (2013).

2 On the status and nature of non-hoplite troop types, for example, see SPENCE (2010: 111 138) on cavalry, TRUNDLE (2010: 139-160) on light troops.

3 On Greek mercenary service generally, see PARKE (1933); GRIFFITH (1935); AYMARD (1967: 487-498); SEIBT (1977); MILLER (1984: 153-160); MARINOVIC (1988); BETTALLI (1995); TRUNDLE (2004); GÓMEZ CASTRO (2012); TRUNDLE (2013: 407-441); and BETTALLI (2013).

4 On Greeks in the mercenary explosion of the later fifth and fourth century BCE see PARKE (1933); GRIFFITH (1935); MILLER (1984: 153-160); MARINOVIC (1988); AYMARD (1967: 487-498); ROY (1967: 292-323); WEISKOPF (1989); FIELDS (1994: 95-113); BETTALLI (1995); FIELDS (2001: 102-38); TRUNDLE (2004) and (2013: 407-441); BETTALLI (2013: 71-109, 147-195, 254-316). 
the numbers of Greek mercenaries in the fourth century BCE. Thus, over ten thousand mainland Greek hoplites served with Cyrus the Younger on his failed expedition against his brother the Great King in $401 \mathrm{BCE}$, several tens of thousands then found service on either side of Persia's attempts to recover Egypt in the 380s, 360s and late 340s, and several thousand also served Satraps and the Great King in the Great Satraps' Revolt of the 360s BCE. Finally, perhaps as many as 50,000 Greeks fought for the Great King of Persia against Alexander's invasion of the Empire in the 330s BCE. It is also possible, indeed likely, that Greeks were not the only mercenaries in service in this period. Thanks however to our Greek sources, we are particularly well informed about their numbers and their nature in the later Classical period.

Many factors, including political, social, demographic, and economic causes contributed to this 'explosion', not to mention military reasons why Persian Kings, their governors, and certain states employed outsiders on the battlefield. That all stated, I argued in my book Greek Mercenaries that increased and then major demand for military personnel lay behind most mercenary activity in the later classical age and that the political chaos and internecine wars of the period explained the rise in mercenary numbers, rather than supply driven by wars on the Greek mainland making men available for service through a combination of poverty and greed. ${ }^{5}$ This paper, therefore, explores the potential causes of mercenary activity through the lens of this fourth century mercenary flow in light of recent ideas with new analyses alongside recent discussions of our ancient evidence.

Many have argued that supply of soldiers available and willing to serve drove mercenary service beyond the mainland Greek states and stoked the explosion of mercenary numbers in the later Classical Period. ${ }^{6}$ Thus, the long drawn out Peloponnesian War produced a generation of Greek citizens trained and used to fighting for a living who then became 'mercenaries', for want of a better term, fighting for others. ${ }^{7}$ Similarly, the poverty of certain regions in the Greek world that provided disproportionately large numbers of mercenaries suggest that supply of available troops from these areas drove mercenary service. The best example of this supply comes from

5 TRUNDLE (2004: 44-79), specifically see 54-62 (supply); $63-68$ (attractions); $70-72$ (political considerations); and $72-79$ (demand).

6 MILLER (1984: 153); PARKE (1933: 228-230); MCKECHNIE (1989: 22-29); CARTLEDGE (1987: 315).

7 On the Peloponnesian Wars as a stimulus for mercenary service see PARKE (1933: 228); MILLER (1984: 153-160); and BETTALLI (2013: 51-69). 
the cities of Arcadia in the central Peloponnese. ${ }^{8}$ Worth noting, however, is perhaps that not all Arcadian mercenary service emanated from poverty. James Roy paints a more optimistic vision of Arcadia as more than simply a mountainous and inhospitable full of land of 'acorn-eaters' as other Greeks styled the Arcadians. ${ }^{9}$ Arcadians served prolifically with Cyrus the Younger in the Anabasis campaign making up a contingent of 4,000 men, a full third of the Greek forces. Greek states were not always able to provide for all their citizens adequately. Small wonder that we can find plenty of examples of men willing to follow others to seek service abroad. At the same time, Greek states were often powerless to control the movement and actions of their people. Two incidents from the fourth century BCE illustrate the limits of Athenian state power alongside the potential rogue military actions of Athenian citizens. The first, found in the corpus of legal speeches attributed to Isaeus concerns an Athenian called Macartatus. ${ }^{10}$ This Macartatus sold his land and bought and equipped a trireme with which he sailed to Crete, presumably on a plundering expedition. He almost started a war between Athens and Sparta. Fortunately for interstate relations he and his ship sank before matters could get out of control. The second incident comes in the form of an inscription seeking to prohibit Athenians from crossing the border to take military service in Boeotia and specifically then against Eretria, an Athenian ally. This decree discussed and translated by Toogood and dated to 357/6 BCE states that 'If anyone from henceforth attacks Eretria or any other of the allied poleis, whether he is from Athens or from one of the Athenians' allies, he is to be condemned to death and his property is to become the state's and a tithe is to be given to the goddess'. ${ }^{11}$

Both incidents cited above illustrate the loose nature of Athenian civic responsibility. On the one hand, individuals strove to better their circumstances, and that of their family, economically and socially through service with others, while on the other the state balanced its duty to its people with a finite resource base with which to redistribute a community's wealth. Nationalism and national identity, if we can apply such terminology, could not transcend the economic needs of the citizens of any Greek polis. Thus,

8 On Arcadian mercenaries see HERMIPPUS 63.18; ARISTOPHANES, Knights 795-800; XENOPHON, Anabasis 1.1.6 and especially XENOPHON, Hellenica 7.1.23; GRIFFITH (1935: 237-238); COOPER (1978 and 1996, vol. 1); FIELDS (1994: 95-113); FIELDS (2001: 102 138); MORGAN (2001: 20-44); NIELSEN (1999: 16-79); TRUNDLE (2004: 52-54); BETTALLI (2013: 182-186).

$9 \operatorname{ROY}(1999: 320-381)$.

10 ISAEUS, Hagnias $11.48-9$.

11 TOD (1948: 2.154. 10-15); TOOGOOD (1997: 295-297). 
mercenary service and associated activities like piracy offered enviable opportunities for enrichment overseas.

Another phenomenon that drove the supply of mercenaries from Greek cities were the exiles who regularly emerged from Greek political strife within poleis in the later fifth and more predominantly in the fourth century BCE. Parke considered these exiles were a potential source of mercenaries and more recently McKechnie has supported this notion. ${ }^{12}$ Certainly, the fourth century witnessed increased political strife within Greek communities. At the same time, more cities suffered destruction and the resulting diaspora of their inhabitants than we know about in the fifth century BCE. ${ }^{13}$ Demosthenes and Isocrates both considered that exiles were a considerable problem in the fourth century. ${ }^{14}$ Isocrates identified wandering Greek exiles in Asia as a potential threat to political stability. ${ }^{15}$ Ancient evidence alludes to exiles in mercenary armies, but specific evidence remains unclear regarding the scale of exiles in mercenary Greek armies. Some Greeks with Cyrus the Younger were exiles. Thus, an un-numbered group of Milesian exiles followed his cause, but Xenophon labels only five of those named Greek mercenaries with Cyrus as exiles. ${ }^{16}$ The evidence is complicated. Indeed, in a noteworthy passage Xenophon tells his readers that most of the men on the campaign had sailed from Greece not due to exile or penury, but because of the attractions of service with Cyrus. ${ }^{17}$ According to him, many had left behind families and homes to which they were keen to return. Other sources tell a different story. On the other hand, Isocrates, for example, stated that Xenophon's men left their homes due to their personal circumstances unable as they were to live in their own cities. ${ }^{18}$ It is still difficult to assess the role that Greek exiles and sheer desperation played in the mercenary phenomenon in the fourth century BCE. No doubt many mercenaries were poor and some had few opportunities elsewhere.

Alongside poverty and exile, one further factor might have influenced the growth of numbers in mercenary service from the Greek cities. Long ago Parke suggested that land shortage might well have underpinned some mer-

12 PARKE (1933: 228, n. 1); MCKECHNIE (1989: 22-29).

13 MCKECHNIE (1989: 28); TRUNDLE (2004: 55).

14 DEMOSTHENES 18 De Corona, 48; ISOCRATES 6 Archidamus, 68.

15 ISOCRATES 5.120-121; see MCKECHNIE (1989: 90).

16 XENOPHON, Anabasis, 1.1.7.

17 XENOPHON, Anabasis, 6.4.8.

18 ISOCRATES 4.146. 
cenary service. ${ }^{19}$ The Greeks did not practice primogeniture, which meant that all sons inherited an equal share of their father's property. The example described in a legal speech of Isaeus 2 in which one of two brothers worked the farm at home, while the other took mercenary service abroad illustrates the point specifically. ${ }^{20}$ Some mercenaries therefore did serve abroad due to issues of land-tenure in Greece. Demographic changes in Greece might also have forced more Greeks to seek opportunities abroad. Greece did suffer from limited supplies of good land, especially arable farmland. Its population even in the Archaic Age might have strained resources. Greek colonies in this earlier period no doubt assisted to alleviate population growth in that period. By the fifth century the founding of colonies overseas had all but ceased. Recent studies have suggested that the population of the Greek world might have risen sharply in the Classical Period peaking in the late fourth century BCE. ${ }^{21}$ Prior to Alexander the Great's conquests, the Persian Empire to the east and the cities of Italy and Sicily in the west provided employment opportunities for Greeks seeking a livelihood abroad. Alexander's eastern anabasis opened up a new world for thousands of colonists and emigrants who followed in his wake. Significantly, for mercenaries seeking employment such a livelihood before the time of Alexander was only possible if would be employers sought such Greeks for employment. Without employment they remained simply outsiders and wanderers without identities.

It seems clear that the evidence both for classical Greek antiquity and for other eras of history does not support the idea that supply led to increased mercenary activity. More recent examples of conflicts that involved large numbers of men in military service show that training, availability and experience for large numbers of citizen soldiers does not in itself translate into large numbers of professionals finding employment in armies across the globe in the aftermath of conflicts. Three twentieth century examples demonstrate this well. The first and second world wars did not produce an explosion in the numbers of mercenaries in the 1920s or the late 1940s and 50s. Similarly, the Vietnam War did not see a marked impact of ex-American servicemen in the wars of decolonization in Africa and Asia. Indeed, the mercenaries who found themselves heavily involved in African wars of liberation and determination primarily came from Europe and often were Europeans who came from countries and had themselves strong links to the

19 PARKE (1933: 14, n. 1).

\section{ISAEUS 2 Menecles 3-5.}

21 See most recently OBER (2015: 3 and passim); for earlier discussion of such a hypothesis see SALLARES (1992), chapter 2 (Demography), especially 94-97. 
African countries in whose conflicts they found themselves. A good example of this is the Belgian servicemen, regularly labeled mercenaries who fought in the Congo in the 1960s and 1970s. Many of these were Belgians with connections to the Belgian colonial Congo and, indeed, strong evidence suggests that American funding deliberately hired men to serve who had such colonial connections. In this way, they might obscure the mercenary nature of the military personnel. ${ }^{22}$

The answer then to the reason why mercenaries exist at all is surely demand. Without the demand for military service there is no employment. Demand even lay at the root of the Belgians sought by American financiers, primarily the $\mathrm{CIA}$, fueling wars in central Africa. ${ }^{23}$ But, and this now worth considering, can demand by itself explain the root cause of all mercenary service. There were of course, and as noted above, always underlying phenomena that had little do with the context of the neo-liberal market-place or in other words supply and demand. In the Greek world, for example, the strong bonds of aristocratic ritualized friendships (xeniai) that cut across polis boundaries, many of which pre-dated the polis itself and which also valorized military service with fellow, but foreign leaders, gave mercenary service an acceptable veneer even in the classical period. ${ }^{24}$ Our evidence suggests that even before the boom in Greek mercenary employment of the later fifth and fourth century BCE of which Arcadians played a central role, Arcadian aristocrats had established military alliance-connections through ritualised friendships that almost certainly help to lay the foundations for the great mercenary opportunities that followed. Thus, Pindar's praise-poetry identifies several Arcadian nobles, Hagesias of Stymphalus, Phormis of Maenalus and Praxiteles of Mantinea in overseas service. ${ }^{25}$ These nobles followed an honourable tradition of the itinerant hero-soldier, like Achilles and other heroes of Troy, travelling abroad in search of war, glory and movable plunder.

In antiquity employment was always considered demeaning and professionalism not respected in the way it is today. Working for another person carried a stigma as it highlighted dependence, subordination and ultimately

22 On modern mercenaries and wars in Africa see GARRISON (1968: 131-141); and THOMAS (1984).

23 On the rise of Private Military Companies in the modern world see CHESTERMAN and LEHNARDT (2007).

24 See in general HERMAN (1987); and MITCHELL (1997).

25 PINDAR, Olympian 6; see Pausanias, 5.27.1; for discussion see BETTALLI (1995: 26). 
a lack of autonomy and even freedom. The Greeks idealised freedom (eleutheria) above most things. In a world in which chattel slavery (douleia) was common freedom represented the extreme and perfect end of a complex continuum. At the same time, of the many kinds of endeavours in which humans engaged, the Greeks idealised farming and fighting. Landholding had become intricately associable with military service in the idealised Greek polis of the fifth century BCE. The hoplite citizen-farmer represented the paradigm of what it meant to belong within the state. Farming and fighting, therefore, intrinsically connected as they were, each had become closely connected to citizenship and ideals of manhood in the world of the fifth and fourth century Greek states. This might explain another reason why Greek citizen males willingly served others as hoplites, even for wages, as military service was a natural part of a citizen's life. Furthermore, if plundered property provided remuneration for military service, then soldiers could hide their real motivation and subordinate their employed or "paid" status beneath a veneer of heroic redistribution of plunder. There was nothing dishonourable in receiving a part of the spoils of war. Homer's heroes set an important precedent in that regard.

Thus, despite the fact that mercenaries in the Greek world were paid they could conceal their employed status through contrived allegiances, motivations and relationships. Greek terminology is useful in this regard to identify mercenaries not as hirelings, but as allies or friends. In early Greek contexts, therefore, mercenaries were termed as epikouroi or xenoi literally fighters-alongside (allies) and foreigners, associable with guest or ritualised friendship. ${ }^{26}$ Even after the introduction of regular wages or misthos in the fifth century BCE, xenos and epikouros continued in use as common markers for Greek mercenaries and in some instances well into the fourth century BCE. ${ }^{27}$ Thucydides used the term epikouros in the early years of the Peloponnesian War as did Xenophon in the first half of the fourth century. ${ }^{28}$ The term misthophoros emerged as a term for mercenaries as the result of the spread of wages in coin in the fifth century BCE. ${ }^{29}$ Misthophoroi as 'wage-bearers' or '-takers' more accurately describes the status of most paid soldiers, but

26 LAVELLE (1997: 229-262); and TRUNDLE (2004: 12-14).

27 TRUNDLE (1998: 1-12).

28 For example, THUCYDIDES 1.115.4; XENOPHON, Hellenica 7.1.23; see LAVELLE (1989: 36-39).

29 TRUNDLE (2004: 15-17). 
even this term suggested others types of more acceptable relationships. The term first appears in Athenian military and political contexts. The Athenian democracy introduced misthos for state-service in juries. As political service was the privilege of citizenship and indeed a marker of identity, so those in receipt of misthos might still conceal their true identity. There was nothing intrinsically dishonourable in taking a wage for service for the state and especially a state that encouraged political service of its exclusive if relatively large citizen-group. Misthophoros and epikouros co-existed in our sources despite the proliferation of coinage as a means of payment. Indeed, Thucydides in the later fifth century uses epikouros (seventeen times) far more regularly than misthophoros (six times). ${ }^{30}$ This suggests the traditional and euphemistic attitude to mercenaries still prevailed.

Finally, in regard to the privileged place of military service in Greek states it was very rare to find slaves serving as infantrymen in Greek armies. Land warfare was the privileged domain of the free and indeed of citizens. Despite the fact that there are examples of non-citizens serving in the armies of Greek states, notably in Sparta where non-Spartiatae made up large numbers of the Spartan heavy infantry army as those who dwelt on the periphery of the state, the Perioekitae, and even freed helots, the so-called 'new-people' or Neodamodeis, most Greek state-armies contained heavy infantry drawn from the citizen group. ${ }^{31}$ This reinforced a citizen and elite identity in military service and gave honor to such service. Such a prestigious mantle meant that those taking service overseas for others could glean the honor of service and military identity regardless of the payment received.

The preconditions for the willingness of Greek citizens to seek service overseas for others that Greek ideology provided and that freedom, landholding and a warrior tradition all supported created the context for Greek mercenary service, but still, as I will continue to argue did not provide the impetus for the Greek mercenary explosion of the later Classical Period. Three separate but related phenomena fuelled the appearance, use and spread of large numbers of Greek mercenaries in classical antiquity: (1) the influence of the east on the Greek world and the demands that eastern rulers had for soldiers from the Greek mainland; (2) the rise of tyrannies in the Greek cities of the Greek mainland, who themselves sought to hire men to protect themselves and their regimes and finally; (3) the introduction and spread

30 TRUNDLE (2004: 13).

31 On the subject of helots and other un-free or even slave-soldiers see HUNT (1998: $31-41,56$ 62). 
of coinage in the Aegean Basin and eastern Mediterranean that enabled the payment of professional servicemen on a larger scale than previously seen. ${ }^{32}$

Importantly, as we have just noted with reference to Arcadians, military tradition played its role in mercenary service too. Greeks had long found service at the courts of eastern rulers. lonians and Carians served in Egypt, Antimenidas in Babylonia, some suggest even Assyrian kings had Greeks in service in the seventh century. ${ }^{33}$ These numbers grew at a steady rate from the later Archaic period and through the fifth century. Traditional networks of friendships also fueled military-mercenary service. Networks connecting men to power and the potential of reward attracted many into service overseas. Personal relationships, like guest or ritualized-friendship (xenia) and more generally just friendship (philia) between ordinary Greeks and the powerful men of the eastern Mediterranean facilitated mercenary service. ${ }^{34}$ Xenophon's Anabasis reveals the importance of networks of relationships to the mercenary army's formation and maintenance. Xenophon highlights the important part played by the noble and generous nature of Cyrus in attracting men into his service and keeping them loyal. ${ }^{35}$ The men who came to Cyrus thought his friendship (philia) was worth more than their home poleis. For example, all who served Cyrus did so for more than a monthly wage. ${ }^{36}$ Proxenus told Xenophon that the friendship of Cyrus was worth more than his native state. ${ }^{37}$ Xenophon tells us that Cyrus told the Greeks that few would wish to return home after he had become king because of the life he could provide for them. ${ }^{38}$ Clearchus told Tissaphernes that he had set his heart on having Cyrus as a friend (philos) because he thought he was most able of anyone to benefit whoever he wanted. ${ }^{39}$ Mercenary service, there-

32 On the importance of Persia for the employment of mercenaries from Greece see TRUNDLE (2004: 73-79); TUPLIN (1987: 167-245); RHODES (2006: 221-222); and BETTALLI (2013: 235-315). On Tyranny's role in mercenary employment see TRUNDLE (2006: 65-76); BETTALLI (2013: 319-360). On the role of coinage in transforming warfare see TRUNDLE (2010: 227-252).

33 BROWN (1997: 300-303).

34 On xenia and philia and mercenary service see HERMAN (1987: 97-105); MITCHELL (1997: 1 1 1-147); PRITCHETT (1974: 59-116); and TRUNDLE (2004:147-164).

35 XENOPHON, Anabasis, 1.9.11-13.

36 XENOPHON, Anabasis, 1.9.17.

37 XENOPHON, Anabasis, 3.1.4.

38 XENOPHON. Anabasis, 1.7.4.

39 XENOPHON, Anabasis, 2.5.11. 
fore, provided opportunities for Greeks (elite and otherwise) to connect with the powerful. The Rhodian generals Mentor and Memnon, each of whom became second in command under the Persian King, demonstrate the point. Mentor first served an Egyptian Pharaoh. Later, he served the Persian King and became very powerful, perhaps as a recruiter of Greek mercenaries. ${ }^{40}$ Memnon replaced his brother and Darius considered him one of his best commanders and he led the Persians after Granicus until his death. ${ }^{41}$

As a testament to the deeper roots that lay behind mercenary relationships than simply mercenary-motivation, so-called Greek 'mercenaries' remained loyal to their employers, despite adverse circumstances. The fact that traditional ties, like xenia, might underpin this loyalty. Mercenaries were therefore less mercenary than we might think. As a result close ties that transcended simple financial reward and remuneration bound men and their so-called employers together. Thus, men appear serving with members of their family even in mercenary contexts, ${ }^{42}$ and from beyond the family connections they served in groups that came from their homes. ${ }^{43}$ Family and civic connections tied mercenaries together abroad. We might note here how the Arcadians in Xenophon's Anabasis showed much national feeling. ${ }^{44}$ Commanders linked these groups of men to their employers in hierarchies of elite- and ritualized-networking. As a result of these networks most mercenary Greeks had close connections to their employers through traditional roots of diplomatic bonds and ties of wider foreign-policy affiliation.

Ties to polis-civic traditional relationships, which themselves often reflected an environment whereby, the saying goes, 'my enemy's enemy is my friend', fed into pre-existing hostilities between Greek communities that might then play out in Greek military service abroad. Mercenary networks usually had much in common with polis 'foreign-policy'. This might explain how rarely Greeks baulked at attacking other Greeks, while serving Persian or Egyptian (or other) paymasters. In one rare example, Diodorus describes how Greeks fighting with Persian forces at Pelusium defended their Egyptian employed countrymen and allowed them to withdraw under a treaty from a Persian attack. ${ }^{45}$ Such panhellenic feeling was indeed rare. Greeks regularly fought

40 For Mentor's career and services see DIODORUS 16.45.1, 16.50.7, 16.52.1.

41 For Memnon as a mercenary commander see specifically DIODORUS 17.7.2, 29.1.

42 See TRUNDLE (2004: 139-143). Inscriptions like SEG 31. 1552, 1554, show family names in the same Greek units in overseas campaigns.

43 TRUNDLE (1999: 28-38).

44 For example, XENOPHON, Anabasis, 6.2.11.

45 DIODORUS 16.49.5. 
against other Greeks both for their own states and for other commanders. The Greeks with the Great King Darius III against Alexander the Great, for example, hated and feared the Macedonians. They knew their best interests lay with the Persians. Ultimately, these Greeks proved more loyal than Darius' fellow countrymen as they attempted to protect the Great King from those who conspired against him in the last days of his life. ${ }^{46}$

The process for hiring mercenaries developed into sophisticated systems, markets and networks. ${ }^{47}$ As we have suggested earlier, traditional relationships of ritualized friendships between aristocratic Greeks and major figures across the eastern Mediterranean initially facilitated military alliances that then converted into more mercenary relationships in the classical period. Such networks subsequently reflected polis based foreign policies and had become an extension of them. Athenian aristocrats often had close associations with elites across the eastern Mediterranean and so could use these connections to facilitate mercenary employment. For example, Iphicrates was related to Thracian kings no doubt enabling the flow of mercenaries from Thrace to Athens and vice versa. Sparta regularly assisted the flow of mercenaries from the Peloponnesian states to its allies abroad, like Dionysius I in Sicily. The Spartans enabled Dionysius to recruit from within the Peloponnese. ${ }^{48}$ We are also told that they sent Peloponnesians, certainly non-Spartiatae, to aid their allies in other wars, most notably to Cyrus the Younger for the Anabasis campaign and to the Phocians in the Third Sacred War. ${ }^{49}$ In the case of the Anabasis campaign, Xenophon explicitly states that Cyrus had requested the Spartan commander Chirisophus to lead the contingent of men the Spartans sent to him from the Peloponnese. Within Greek cities wealthier men also made possible hiring troops and these according to Aeneas also should accommodate mercenaries inside the city at their expense. ${ }^{50}$ Hiring practices, therefore, facilitated by elite connections overseas and traditional relationships fuelled the demand for mercenaries in the classical period.

It is important now to pause and consider then 'Who are mercenaries both generally and more specifically?' Definitions are important here. I think it

46 ARRIAN Anabasis 3.21.4; DIODORUS 17.27.2; CURTIUS 5.8.4.

47 See TRUNDLE (2004: 104-131).

48 DIODORUS 14.44.1-2, 58.1.

49 XENOPHON, Anabasis 1.4.3 and DIODORUS 16.24.2.

50 TRUNDLE (2004: 104-1 17); for example, see AENEAS Tacticus 13.1 and 22.29. 
is very rare to find a genuine mercenary prepared to fight for just anybody and only interested in service for the money. As I noted above ancient Greek mercenary service dovetailed closely with both traditional friendship networks and with aristocratic-state foreign policy. How does this change the way in which we understand mercenary service when we consider mercenary service in antiquity more generally? In short it means that there were levels of reciprocity between employers and employed that changed the dynamic in the choices made regarding employment and hiring practices. The absence of genuine 'condottieri' who might switch sides at a whim or serve any paymaster curtailed the role that the free-market played in Greek mercenary activity. By which I mean, there was no free-market or genuine individual mobility in classical Greek mercenary circles. The processes that drove Greek mercenary service were so embedded in traditions of ritualized-friendships and polis foreign-policy constraints that these determined who served where and for whom they fought. It makes identifying those men in mercenary service as 'mercenaries' obsolete, or at least misleading, and as we have seen above Greek terminology did not identify mercenaries as the type of soldiers of fortune that we might recognize in the present age.

In addition to this point, the types of people who found themselves in mercenary service often reflected, at least in an underlying causal way, the reasons for their hiring. Marco Bettalli recently identified mercenaries as coming from three groups or three types of people. ${ }^{51}$ First, young men seeking fortune and adventure based often on family traditions. This might then explain the presence overseas, especially in archaic contexts, of aristocrats like the brother of Alcaeus named Antimenidas or Arcadian nobles noted in Pindar's praise poetry serving foreign rulers - both of which harkened back to Homeric heroes adventuring on military service overseas. The second group he identifies came from those seeking refuge abroad from their communities - here we might identify the large numbers of Arcadians and Achaeans on the Anabasis campaign and Arcadian mercenary traditions more in the fourth century BCE. Finally, there were numbers of men coming from states which essentially exported surplus populations to service also based on traditions of serving foreigners. The Arcadians escaping the poverty of the central Peloponnese or even perhaps the tyranny of Spartan imperialism may also be in this group.

Of the three groups or types of men seeking mercenary service, the first group, the individuals seeking adventure as young men, are clearly distinct 
from those in the second and third categories of those seeking employment en masse from endemic domestic circumstances of poverty or other hardships. Unfortunately, though, any kind of large scale military service still requires the will and the need of employers to enlist and support foreign servicemen in their armies. As we have stated, clearly, mercenary service is - and was - a demand driven industry and not at all driven by supply. No matter how many wanted to become mercenaries in the Greek world without employment these want to be soldiers remained idle and unemployed. Without employment there are no mercenaries.

So, returning to the question 'Why do people hire mercenaries?', then a key preliminary criterion is: 'Who is doing the hiring and for what purpose?' Tyrants hired mercenaries for very different reasons than democratic states even though both did - and do - in fact hire mercenaries to fight their wars. Tyrants hired men to protect their person and because they distrusted the people over whom they ruled to fight for their interests. Indeed, even in the Greek world tyrants regularly disarmed the local population in order to rule over them. The best example of this is perhaps Peisistratus who disarmed the Athenians through a trick. ${ }^{52}$ Aristotle went so far as to distinguish a king from a tyrant by the existence for the latter of a hired bodyguard of mercenaries (xenoi - literally foreigners), while the former's bodyguard was made up of citizens. ${ }^{53}$ Sicily became a hotbed of mercenary activity when tyranny became well established on the island, especially at Syracuse under Dionysius $1 .{ }^{54}$ Our sources paint a grim picture of the tyrant's use of mercenaries to hold the Syracusan people in slavery. ${ }^{55}$ Dionysius exploited mercenaries further for his wars against Carthage. So much was this the case that Sparta acted practically as a supplier of Peloponnesian mercenaries to Dionysius in the early years of the fourth century BCE. Just as in the case of the Persian Empire mercenaries in the service of one side fueled mercenary service on the other. Thus, the Carthaginians became employers of Greek mercenaries in their wars against the Greeks of eastern Sicily. ${ }^{56}$

Mercenaries then represented markers of power relationships for individual rulers whether these were kings or tyrants. The same can be said of the

52 ARISTOTLE, Ath. Pol. 15.3-5.

53 ARISTOTLE, Politics, $1311 \mathrm{la}$

54 Most recently see BETTALLI (2013: 331-345); for examples see DIODORUS 14.44.1-2, 58.1, 15.17.3.

55 DIODORUS 14.65.2-3; PARKE (1933: 68).

56 PLUTARCH, Timoleon, 30 and DIODORUS, 16.81.4. See TRUNDLE (2004: 74). 
Persian rulers in western Asia. The Satraps and the Persian Kings appear to have hired mainland Greeks over whom neither held physical imperial sway principally because they could not trust their own Greeks in Asia Minor, or other local native groups to fight for them willingly. If they did then that too would have ramifications of the power dynamic between ruler and ruled in specific regions of the Persian Empire. The irony was of course that this meant that large numbers of Greeks from outside of the boundaries of the Empire ended up fighting on either side of conflicts between the King and his rivals, for example in Egypt during Persia's three attempts to subdue the country in the fourth century BCE. In this way, mercenary service could be seen to have developed its own dynamic with each side hiring men because the other side was doing the same. But the salient point to make regarding the wars of the Persian king against his enemies from Cyrus' failed coup to the Great Satraps Revolt remains that hired troops from overseas were the easiest and least politically compromising way to wage wars for control of the western Persian Empire.

Democracies too hired mercenaries. Wars often prove unpopular both with the community at large, but also with those specifically asked to fight in them. Money became the means to offset the need to make citizen soldiers fight in unpopular wars and to secure men for military service in the absence of responsibility of citizen servicemen or responsibilities to those enrolled for service. The role of coinage in mercenary service was central. De Ste Croix noted this point when he suggested that Greek mercenaries were the first example of mass hired labor in history. ${ }^{57}$ Athenian coinage transformed military relationships and in turn created professionals out of military personnel, even citizen soldiers. This occurred first at sea in the Athenian navy, but slowly and surely on land. ${ }^{58}$ The ideology of money in place of voluntary manpower appears clearly in the speeches at the start of the Peloponnesian war in which Pericles details the role of money in hiring men for military service as opposed to citizen militias, especially the juxtaposition of naval with infantry personnel. ${ }^{59}$ Eighty years later Demosthenes outlines a very similar ideology in his plans for military activity in Thrace, hiring men with offers of money for food and payment from plunder. ${ }^{60}$ Jason Crowley recently noticed that Athens was a major employer of mercenaries rather than provider of them based primarily on Athenian ability

57 CROIX (1981: 182).

58 For discussion see TRUNDLE (2010a: 227-252).

59 THUCYDIDES 1.141.5.

60 DEMOSTHENES 4.28-29. 
to pay its citizens and by extension other state's citizens for service. ${ }^{61}$ This was due, as he suggests, to Athens' 'aggressive imperial orientation', but we might add to this Athenian wealth and the proliferation of Athenian coinage. Coinage became the tool that enabled mercenary activity like no other. It turned Athens into a city of mercenary service. Athenian citizens received payment for jury service and even other political posts. By the later fifth century BCE payment for military service had become very common in both naval and land warfare. Thus, not only could Athens pay its citizens to serve the state it could afford to pay non-Athenians too, at least in the fifth century imperial period. The role of the navy was central in this. The navy required two things that land warfare had traditionally not needed or if it did need them it never acknowledged that need. The first of these was enormous numbers of oarsmen drawn from the poorer status group of society - the thetes. These men absolutely required remuneration for their service. Secondly, the ships in the fleet required technical specialists to man the ships as navigators, steersmen, carpenters and other experts with skills that gave seamanship a degree of professionalism previously not seen, and once again perhaps that had never been acknowledged in land warfare. Through the fifth century the Athenian navy became increasingly professional as crews manned Athenian ships for payment in Athenian coin from all over the Aegean. ${ }^{62}$ Indeed, one key inscription shows that in addition to Athenians, Metics and Greeks from within the Athenian naval archê approximately twenty percent of the named crew members were listed as slaves..$^{63}$ Payment was made in coin to all, though of course the slaves' pay would have gone to the master. This clearly illustrates the processes that coinage set in motion in transforming warfare into a more mercenary activity in the Athenian classical world. Coinage, therefore, as a tool and medium of exchange became both the means and the end of empire. Unsurprisingly, in such an environment mercenary interests predominated.

The legacy of the Athenian military system with its focus on coins as the means of waging warfare influenced the subsequent war-making of the fourth century BCE. Thus, the same point as shown for the Athenian Empire can be made regarding Philip II of Macedon in the fourth century and his use of coins. ${ }^{64}$ Philip's coinage flooded the Aegean world thanks to his con-

61 CROWLEY (2012: 208, n. 36).

62 See TRUNDLE (2016: 65-79); THUCYDIDES 1.121.3, 143.1-2, 7.63.3.

63 Insciptiones Graecae 1(3) 1032.

64 See, in general, MARTIN (1985); BORZA (1995: 37-55). 
trol of the mines in the region of his new foundation at Philippi (Pangaeum) and then dominated the Greek world. ${ }^{65}$ In a well-known passage Diodorus comments on how Philip's control of the mines made Philip very wealthy and enabled him to pay soldiers and bribe Greeks alike to further his power abroad. ${ }^{66}$ Like the Athenians before him he became a prolific employer of foreigners both in his military and for his state. He professionalized his Macedonian national army. One Greek commentator noted how Philip had made prostitutes of those Greeks who flocked to him and his court seeking his money. ${ }^{67}$ Coinage acted as both a tangible benefit of military service, but also a symbol of the particular-bond between paymaster and wage-taker. This, of course, like so much in the classical world has Homeric roots to justify the relationship based in military connections and plundered property as the basis of the rewards of service.

Money fuelled the proliferation of mercenary service. Of course, it is conceivable that hiring mercenaries was cheaper than using a state's own citizen soldiers especially in the classical age when states like Athens had already begun to provide their own citizen troops with not only supplies and food for campaigns but also payment for their service. Economics, therefore, should not be overlooked in considering why employers hired mercenaries. In several ways, therefore, it might well have been cheaper to hire mercenaries. Firstly, hiring men for a single campaign might have had little impact on a state's resources, especially if the campaign was successful and yielded plunder in excess of the costs of the war. Furthermore, there was clearly no responsibility for training or equipping men hired from outside of the community. The problem came only when wars did not pay for themselves and men go un-remunerated for their service. We have very few stories from the classical period of states having major problems with their mercenaries. There is nothing in classical Greek history to compare with The Mercenary or Truceless War fought between Carthage and its mercenaries at the end of the First Punic War in 241 BCE. In that war, Carthage came close to destruction. We have noted how lsocrates thought roving bands of displaced Greeks presented a problem for Asia Minor in the fourth century. ${ }^{68}$ There are isolated stories of discharged or unemployed mercenaries causing trouble as they travelled from one place to another. Thucydides' account of the Thracian Dii who arrived too late to travel to Sicily with Dem-

65 See TRUNDLE (2010a: 227-252) for the main points of this argument.

66 DIODORUS 16.8.7.

67 THEOPOMPUS in FGrH 115 225-226.

68 ISOCRATES 6 Archidamus, 68. 
osthenes and who on their return home destroyed the city of Mycalessus in Boeotia speaks volumes for the possible consequences of armed men deprived of employment. ${ }^{69}$ Diodorus preserves a series of stories concerning the survivors of the defeat of Phocis in the Third Sacred War that sees these mercenaries pillaging in the Peloponnese before then seeking employment (and plunder) across the Mediterranean and causing chaos in their wake. ${ }^{70}$ Diodorus follows their movements after their defeat and desertion of Greece in order to highlight their eventual defeat and destruction in slavery or death..$^{71}$ The fact that such stories are relatively uncommon and peripheral to Greek polis warfare suggests a degree of 'order', even in the fourth century. Perhaps this was due to the fact that there was enough employment for mercenaries in the period to alleviate brigandage on a large scale.

We have already noted several times the social basis of some mercenary service. In the Greek-World the basis of much military service that we might style as mercenary lay with ritualized-friendships promulgated on Xenia. Aristocratic connections that supported the status of warriors in a warrior society, and mutual gift giving that was itself a form of remuneration, usually in the form of redistribution of booty, all in turn blurred what look very much like mercenary relationships. In effect, of course this also provided mutual support between elites of different polities and meant that those same elites did not need to rely so heavily on men from within their own communities for military support. This point we have already made with regard to tyranny and imperial control in the Aegean and eastern Mediterranean. Service engenders obligation towards and empowerment of those in service. Hence it was important to exclude certain groups from military service on land as a matter of course like slaves and subjects (unlike at sea where the bearing of arms was not a prerequisite).

Finally, we come to the various military reasons for hiring mercenaries. Mercenaries provided skilled and experienced men to augment the strength of states' armies. They sometimes provided specialists otherwise missing from certain forces. Thus, it was not uncommon for Greek states to hire skilled light infantry, like peltasts, archers and slingers from peripheral regions of the Aegean basin to augment their own heavy infantry arm. ${ }^{72}$ Likewise

69 THUCYDIDES 7.27 and 29 .

70 DIODORUS 16.61.4-16.63.4.

71 DIODORUS 16.63.1-4.

72 On light troops especially see generally van WEES (2004); BEST (1969); TRUNDLE (2010b: 139-160). 
Persian Kings and their satraps required Greek hoplites to provide a heavy infantry wing to support their larger numbers of light troops and cavalry. ${ }^{73}$ This is yet another reason to believe that mercenary service was demand driven. Employers sought out specialists and skilled soldiers. Mercenaries too might have had tactical and strategic abilities not found amongst local populations or civilian militias. Aristotle makes this point alongside a criticism of mercenaries as soldiers in his Nicomachian Ethics. ${ }^{74}$ He praised mercenaries (epikouroi) for their fighting skills and ability to inflict casualties, but he goes on to state that professional soldiers often prove cowards when faced with superior arms or numbers, unlike citizen-militia who would more likely die fighting. Such arguments reveal the depth of Greek idealism regarding citizens as non-specialist, unprofessional soldiers juxtaposed with the realities of mercenaries as quality troops.

Finally, it has recently been suggested to me that none of these technical military considerations applied to hiring Greek mercenaries. Hans van Wees gave a paper in Dublin in June 2016 in which he demonstrated that there were plenty of heavy infantrymen in Near Eastern communities in later Archaic and Classical contexts and so the need of the Assyrians or the Persians to employ Greek hoplites was not necessarily to provide a heavy infantry arm that was otherwise missing from Near Eastern armies. ${ }^{75}$ Indeed, one suggestion might then be that the cause that underpinned hiring Greeks into the armies of the Persian Kings and his Satraps was simply to increase the numbers of men one had at one's disposal for any given conflict. This is an interesting notion and needs more consideration. The very large on-paper numbers of Greek hoplites with Persian forces at key moments in the fourth century might well illustrate this point. For one example, we might note the twenty thousand who fought at Granicus and the thirty thousand at Issus against Alexander the Great. ${ }^{76}$ Rather than a small number of highly specialized and well trained men, our sources thus point to tens of thousands of Greeks abroad throughout the fourth century BCE. Numbers on ancient battlefields mattered. Mercenaries were also expendable even if they remained assets. Mercenaries were still outsiders even if they were connected

73 PLATO, Laws, 3.697e; XENOPHON, Cyropedia 8.8.25; ISOCRATES 4.41. For discussion see also SEIBT (1977: 121-162); BETTALLI (1995: 25); BRIANT (1996: 806-807); and TRUNDLE (2004: 71-74).

74 ARISTOTLE, Nicomachean Ethics 3.8.9.

75 VAN WEES (2016).

76 For accounts of the battle of Granicus see ARRIAN 1.13-16; DIODORUS 17.19-21; PLUTARCH, Alexander 16; for Issus see ARRIAN 2.5-14; DIODORUS 17.32-9; PLUTARCH, Alexander 20 1; CURTIUS 3.2-13. 
by ties of friendship and alliances as I have argued above. No doubt they gave employers a good deal of flexibility on the battlefield balancing paid professionals against unpaid militia. To understand mercenary employment as just a way of increasing military numbers is overly simplistic, but it would explain, like the several other phenomena highlighted in this discussion, the enormous numbers of troops in Persian service in the period.

To conclude this argument, the employment of mercenaries, or perhaps more accurately paid outsiders, to fight for employers lay centrally with the employer or paymaster (misthodotês) as the Greeks called him. Without this paymaster, no service was possible and no remuneration was forthcoming. The demand driven industry that emerged in the Greek world of the fifth and fourth centuries BCE and that led to an explosion in the numbers of mercenary soldiers rests firmly with the chaos that engulfed the Persian Empire in the west as Egyptian Pharaohs and Satraps sought independence from the Great King. Similarly in the west Sicilian tyrants fought the Carthaginians and each other in several major encounters. This demand continued through the whole century and even increased in momentum from the time of Cyrus the Younger in 401 BCE whose employment of Greeks is well documented to the campaigns of Alexander the Great in his successful, but ultimately destructive invasion of Persia in 334 BCE. After Alexander, professional soldiers continued to abound in the wars of the successors. Those who fought for Alexander's empire continued to need soldiers, especially Greek and Macedonian soldiers to serve in their armies and for their wars against one another. Arguably these successor wars were themselves a high-water mark for mobile and professional military service. But, in the end, these wars marked the end of the process of mercenary mobility and mass mercenary employment that the classical age had witnessed. The stable kingdoms that emerged from these wars created a new kind of military environment in which paid, but more sedentary and long term professional and garrison soldiers replaced the mercenaries of the fourth century BCE. ${ }^{77}$ Mercenaries continued in the service of kings and poleis in the Hellenistic world, but on nothing like the scale seen in the earlier period.

77 For the changed environment of the Hellenistic period see PARKE (1933: 206-226); GRIFFITH (1935: 33-56); AUSTIN (1986: 450-466); BILLOWS (1990: 292-305); BILLOWS (1995: 146 182); FOULON (1995: 211 -218); LAUNEY (1987); CHANIOTIS (2005: 78-101); SEKUNDA (2007: 343-349); and TRUNDLE (2008: 103-116). 


\section{BibLIOGRAPHY}

AYMARD, A., (1967): "Mercenariat et l'histoire grecque". ÍD. (ed.), Etudes d'histoire ancienne. Paris, Presses Universitaires de France, pp. 487-498. AUSTIN, BAKER, P. (1999): "Les mercenaires". PROST, F. (ed.), Armées et Sociétés de la Grece classique. Paris, Editions Errance, pp. 240-255.

BETTALLI, M. (1995): I mercenari nel mondo greco. Dalle origini alla fine del $v$ sec. a. C. Pisa, ETS.

BETTALLI, M. (2013): Mercenari. Il mestiere delle armi nel mondo greco antico. Rome, Carocci Editore.

BILLOWS, R. (1990): Antigonos One-Eyed and the Creation of the Hellenistic State. Berkeley, University of California Press.

BILLOWS, R. (1995): Kings and Colonists: Aspects of Macedonian Imperialism. Leiden, Brill.

BRIANT, P. (ed.) (1996): Dans les Pas des Dix Mille. Toulouse, Actes de la Table ronde internationale.

BROWN, R.B. (1983): "Greeks in Assyria: Some Overlooked Evidence". Classical World, n 77, pp. 300-303.

BURCKHARDT, L. (1996): Soldner und Burger als Soldaten fur Athen: Aspekte der politschen und militarischen rolle Athenische burger im Kriegswesen des 4 jarhunderts v. Chr. Stuttgart, Franz Steiner Verlag.

CARTLEDGE, P. (1987): Agesilaos and the Crisis of Sparta. Baltimore, Johns Hopkins University Press.

CHANIOTIS, A. (2008): War in the Hellenistic World: A Social and Cultural History. London, Wiley-Blackwell.

CHESTERMAN, S. and LEHNARDT, C. (2007): From Mercenaries to Market: The Rise and Regulation of Private Military Companies. Oxford and New York, Oxford University Press.

COOPER, F. A. (1978): The Temple of Apollo at Bassai: A Preliminary Study. London, Garland Publishing Inc.

COOPER, F. A. (1996): The Temple of Apollo at Bassai. Princeton, Princeton University Press.

CROIX, G. E. M. de Ste, (1981): The Class Struggle in the Ancient Greek World. London, Duckworth.

CROWLEY, J. (2013): The Psychology of the Athenian Hoplite. Cambridge, Cambridge University Press.

FIELDS, N. (1994): "Apollo: God of War, Protector of Mercenaries". SHEEDY, K. (ed.), Archaeology in the Peloponnese. Oxford, Oxbow Books, pp. 95-113. 
FIELDS, N. (2001): "Et in Arcadia Ego". Ancient History Bulletin, n 15, pp. 102-38.

FOULON, E. (1995): "Misthophoroi et Xenoi Hellenistiques". Revue des etudes grecques, $\mathrm{n}^{\circ} 108$, pp. $211-218$.

GARRISON, L. (1968): "White Mercenaries on a "Rabbit Hunt". ROBINSON, D. (ed.), The Dirty Wars: Gorilla Action and Other Forms of Unconditional Warfare. New York, Delaconte Press, pp. 131-141.

GATTINONI, F.L. (1994): "I mercenari nella politia ateniesi dell'eta di Alessandro i soldati e ufticali merceari ateniesi al servizio della Persia". Ancient Society, $\mathrm{n}^{\circ} 25$, pp. 33-61.

GOMEZ CASTRO, D. (2012): Relaciones Internacionales Y Mercenariado Griego: Del Final de la Guerra del Peloponneso a la Paz del Rey (404-386 A.C.). Barcelona, Publicaciones y Edicions de la Universitat de Barcelona. GRIFFITH, G.T. (1935): The Mercenaries of the Hellenistic World. Cambridge, Cambridge University Press.

GUARDUCl, M. (1953): "Arcadia in Sicily". La Parola del Passato, n 8 , pp. 209-10.

HANSON, V. D. (1995): The Other Greeks: The Family Farm and the Agrarian Roots of Western Civilisation. Nueva York, The Free Press.

HERMAN, G. (1987): Ritualised Friendship and the Greek City. Cambridge, Cambridge University Press.

HUNT, P. (1998) Slaves, Warfare and Ideology in the Greek Historians. Cambridge, Cambridge University Press.

IAPICHINO, L. (1999): "I Diecimila di Senofonte: techniche di combattimento, equipaggiamento militare e approvvigionamento degli strumenti di Guerra". Rivista Storica dell'Antichità, $\mathrm{n}^{\circ}$ 29, pp. 91-105.

KAPLAN, P. (2002): "The Social Status of the Mercenary in Archaic Greece". GORMAN, V. B. and E. W. Robinson (eds.), Oikistes: Studies in Constitutions, Colonies, and Military Power in the Ancient World. Offered in Honor of A. J. Graham. Leiden Brill, Leiden, pp. 229-243.

KNAPP, R. (2002): "Greek Coinage, Mercenaries, and Ideology". Eulimene, $\mathrm{n}^{\circ}$ 3, pp. 183-196.

KRASILINIKOFF, J.A. (1992): "Aegean Mercenaries in the Fourth to Second Centuries B.C.: A Study in Payment, Plunder and Logistics of Ancient Greek Armies". Classica et Mediaevalia, n 43, pp. 23-36.

KRASILNIKOFF, J. A. (1993): "The Regular Payment of Aegean Mercenaries in the Classical Period". Classica et Mediaevalia, n 44, pp. 77-95.

LANDUCCI, G.F. (1994): "I mercenari nella politia ateniesi dell'eta di Ales- 
sandro i soldati e ufticali mercenari ateniesi al servizio della Persia". Ancient Society, $\mathrm{n}^{\circ} 25.1$, pp. 33-61.

LANE FOX, R. (2004): The Long March: Xenophon and the Ten Thousand. New Haven, Yale University Press.

LAUNEY, M. (1987): Recherches sur les armées hellénistiques. Paris, Editions de Boccard.

LAVELLE, B.M. (1989): "Epikouroi in Thucydides". American Journal of Philology, n 110 , pp. 36-39.

LAVELLE, B.M. (1997): "Epikouros and Epikouroi in Early Greek Literature and History". Greek, Roman and Byzantine Studies, n 38, pp. 229-262.

McKECHNIE, P. (1989): Outsiders in the Greek Cities in the Fourth Century B.C. London and New York, Routledge.

McKECHNIE, P. (1994): "Greek Mercenary Troops and their Equipment". Historia, n 43 , pp. 297-305.

MARINOVIC, L.P. (1988): Le mercenariat grec au IVe siècle av. n.e. et la crise de la polis. Paris, L'Université de Besançon.

MARTIN, T. R. (1985): Sovereignty and Coinage in Classical Greece. Princeton, Princeton University Press.

MILLER, H. F. (1984): "The Practical and Economic Background to the Greek Mercenary Explosion". Greece and Rome, n 31, pp. 153-160.

MITCHELL, L. G. (1997): Greeks Bearing Gifts: The Public Use of Private Relationships in the Greek World. Cambridge, Cambridge University Press. MORGAN, C. (2001): "Symbolic and Pragmatic Aspects of Warfare in the Greek World of the Eighth Century BC". BEKKER-NIELSEN, T. and L. HANNESTAD (eds.), Historik-filosofiske Skrifter 22: War as a Cultural and Social Force: Essays on Warfare in Antiquity. Copenhagen, Det Kongelige Danske Videnskabernes Selskab, pp. 20-44.

NIELSEN, T. (1999): "The Concept of Arkadia - The People, The Land, and Their Organisation". ÍD. and J. ROY (eds.), Defining Ancient Arkadia: Acts of the Copenhagen Polis Centre, vol 6. Copenhagen, Copenhagen Polis Centre, 16-79.

NUSSBAUM, G. B. (1959): "The Captains in the Army of the Ten Thousand". Classica et Mediaevalia, $\mathrm{n}^{\circ}$ 20, pp. 16-29.

Nussbaum, G. B. (1967): The Ten Thousand: A Study of Social Organisation and Action in Xenophon's Anabasis. Leiden, Brill.

OBER, J. (2015): The Rise and Fall of Classical Greece. Princeton, Princeton University Press.

PARKE, H. W. (1933): Greek Mercenary Soldiers from Earliest Times to the 
Battle of Ipsus. Oxford, Clarendon Press.

PERLMAN, S. (1976-7): "The Ten Thousand: A Chapter in the Military, Social and Economic History of the Fourth Century". Rivista Storicha dell'Antichità, n 6-7, pp. 241-84.

PRITCHARD, D. M. (2010): "The Symbiosis between Democracy and War: The Case of Ancient Athens". PRITCHARD, D. M. (ed.), War, Democracy and Culture in Classical Athens. Cambridge, Cambridge University Press, pp. 1-62.

PRITCHARD, D. (ed.), War, Culture and Democracy in Classical Athens. Cambridge, Cambridge University Press, pp. 111-138.

PRITCHETT, W. K. (1974): The Greek State at War, vol. 2, Berkeley, University of California Press.

RAHE, P. (1982): "The Military Situation in Western Asia on the Eve of Cunaxa". American Journal of Philology, $n^{\circ} 103$, pp. 79-98.

RIDLEY, R. (1979): "The Hoplite as Citizen: Athenian Military Institutions in their Social Context". Antiquité Classique, n 48, pp. 508-548.

ROY, J. (1967): "The Mercenaries of Cyrus". Historia, n 16, pp. 292-323. ROY, J. (1999): "The Economies of Arkadia". NIELSEN, T. H. and ÍD. (eds.), Defining Ancient Arkadia: Acts of the Copenhagen Polis Centre vol. 6, Copenhagen, Copenhagen Polis Centre, pp. 320-381.

SALLARES, R. (1991): The Ecology of the Ancient Greek World. Ithaca, Cornell University Press.

SEELINGER, R. A. (1997): "The Case of Seuthes and Xenophon's Success in the Anabasis: A Conflict of Values". Classical Bulletin, n' 73.1, pp. 23-30. SEIBT, G. (1977): Griechische Soldner im Achaimenidenreich. Bonn, Habelt.

SPENCE, I. (2010): "Cavalry, Democracy and Military Thinking in Classical Athens". STRONK, J. P. (1995): The Ten Thousand in Thrace: An Archaeological and Historical Commentary on Xenophon's Anabasis VI-VII. Amsterdam, J. C. Gieben.

SULLIVAN, B.J. (2011): "Paying Archaic Greek Mercenaries: Views from Egypt and the Near East". Classical Journal, n ${ }^{\circ} 107$, pp. 31-61.

RHODES, P. J. (2006): A History of the Classical Greek World 479-323 BC. London, Blackwell Publiching.

SEKUNDA, N. (2007): "Military Forces: Land Forces". SABIN, P., WEES, H. van, and M. WHITBY (eds.), The Cambridge History of Greek and Roman Warfare vol. 1: Greece, the Hellenistic World and the Rise of Rome. Cambridge, Cambridge University Press, pp. 325-356 
TAGLIAMONTE, G. (1994): I Figli di Marte: Mobilita e Mercenariato Italici in Magna Greci Sicilia. Rome, Archaeologica 15.

THOMAS, G. S. (1984): Mercenary Troops in Modern Africa. London, CO, Westview.

TOD, M. N. (ed.), (1948): A Selection of Greek Historical Inscriptions, Oxford, Oxford University Press.

TOOGOOD, N. (1997): "Athens Aids Eretria: A State's Jurisdiction over its Citizens'

Actions". The Classical Quarterly, n 47, pp. 295-7.

TOURRAIX, A. (1999): "Les mercenaries grecs au service des Achéménides". BRUN, P. (ed.), Guerres et sociétés dans les mondes grecs 490-322. Paris, Editions du Temps, pp. 201-16.

TRUNDLE, M. F. (1998): "Epikouroi, Xenoi and Misthophoroi in the Classical Greek World". War and Society, n' 16, pp. 1-12.

TRUNDLE, M. F. (1999): "Identity and Community Among Greek Mercenaries in the Classical World: 700-323 BCE". Ancient History Bulletin, $n^{\circ}$ 13, pp. 28-38.

TRUNDLE, M. F. (2004): Greek Mercenaries from the Late Archaic Age to Alexander the Great. London and New York, Routledge.

TRUNDLE, M. F (2006): "Money and the Great Man in the Fourth Century BCE: Military Power, Aristocratic Connections and Mercenary Service". LEWIS, S. (ed.), Ancient Tyranny. Edinburgh, University Press Edinburgh, pp. 65-76.

TRUNDLE, M. F. (2010a): "Coinage and the Transformation of Greek Warfare". FAGAN, G. and M. F. TUNDLE (eds.), New Perspectives on Ancient Warfare. Leiden, Brill, pp. 229-252.

TRUNDLE, M. F. (2010b): "Light Troops in Classical Atthens". PRITCHARD D. (ed.), War, Culture and Democracy in Classical Athens. Cambridge, Cambridge University Press, pp. 139-160.

TRUNDLE, M. F. (2013): "Professional Soldiers in Antiquity". TRITLE, L. and CAMPBELL, B. (eds.), The Oxford Handbook of War. Oxford, Oxford University Press, pp. 407-441.

TRUNDLE, M. F. (2016): "Coinage and the Economics of the Athenian Empire". ARMSTRONG, J. (ed.), Circum Mare: Themes in Ancient Warfare. Leiden, Brill, pp. 65-79.

TUPLIN, C. (1987): "Xenophon and the Garrisons of the Achaemenid Empire". Archaeologische Mitteilungen aus Iran, $n^{\circ}$ 20, pp. 167-245. 
TUPLIN, C. (1999): "On the Track of the Ten Thousand". Revue des etudes anciennes, $\mathrm{n}^{\circ}$ 101, pp. 331-366.

WEES, H. van. (2004): Greek Warfare: Myths and Realities. London, Duckworth.

WEES, H. van, (2016): "The Eastern Way of War: hoplites and their nonGreek cousins". Paper Presented in SOUZA, Philip de (organizer), New Approaches to Ancient Greek Warfare, University College Dublin.

WEISKOPFF, M. (1989): The So-Called 'Great Satraps' Revolt' 366-360 B.C.: Concerning Local Instability in the Achaemenid Far West. Stuttgart, Franz Steiner Verlag.

WHITEHEAD, D. (1991): "Who Equipped Mercenary Troops in Classical Greece?". Historia, n 40, pp. 105-113.

YALICHEV, S. (1997): Mercenaries of the Ancient World. London, Constable. 